\title{
Second Attempt of Guided Tissue Regeneration on a Previous Successfully Grafted Site with Periodontal Breakdown-A 5-Year Follow-up
}

\author{
Lean Heong Foo ${ }^{1, \odot}$ \\ ${ }^{1}$ Periodontic Unit, Department of Restorative Dentistry, National \\ Dental Centre Singapore, Singapore
}

Address for correspondence Lean Heong Foo, DDS, MDS, M Perio RCSEd, FAMS, National Dental Centre Singapore, 5, Second Hospital Avenue, 168938 Singapore

(e-mail: foo.lean.heong@singhealth.com.sg).

\begin{abstract}
Keywords

- guided tissue regeneration

- periodontal breakdown

- periodontal maintenance

- risk factors

Guided tissue regeneration (GTR) has been proven to promote attachment and regeneration of periodontal tissue. However, there is a 20 to $40 \%$ incidence of attachment loss on regenerated attachments reported in the literature. To my knowledge, this is the first case report on a second attempt in GTR on a previous successful grafted site with clinical attachment loss. A healthy 17 -year-old Chinese male patient had GTR performed with xenograft particles and bovine resorbable membrane on his root-canal treated, fused upper right lateral incisor and upper right canine (\#12-\#13) in 2007. Probing depth on the mid-palatal region of \#12-\#13 was reduced to $4 \mathrm{~mm}$ and maintained for the next 4 years. But in the fifth year, probing depth increased to $11 \mathrm{~mm}$ with no endodontic symptoms, and a second attempt of GTR using the same materials was carried out. The probing depth at the surgical site was reduced to $4 \mathrm{~mm}$ and successfully maintained for another 5 years. Irregular maintenance and the presence of plaque retentive factor could have caused the clinical attachment loss on \#12-\#13. This case shows it is possible to attempt GTR on a previous successfully grafted site. GTR did not increase tissue resistance against periodontal breakdown. Hence, proper maintenance planning for GTR sites is important to prevent periodontal breakdown.
\end{abstract}

\section{Introduction}

Guided tissue regeneration (GTR) has been proven to reduce periodontal pocket depth (PD) and improve clinical attachment level (CAL) in infrabony defects. In general, the success and stability of GTR are related to good plaque control, deep and narrow intrabony defect $(>3 \mathrm{~mm}$ ) and thick soft tissue $(>1 \mathrm{~mm})$, GTR protocol with good wound stability, and a good postoperative regime with an adequate healing period. ${ }^{1}$ Although predictable surgical techniques and suitable indications for GTR have been well reported in the literature, information on planning maintenance for GTR sites and management of CAL loss on the regenerated attachment remain scarce. Recurrence of CAL loss after GTR was reported to be about 1 to $4 \mathrm{~mm}$ in $20.8 \%$ (5/24) and 36.4\% (4/11) of sites respectively in 5 years ${ }^{2,3}$ and $26.7 \%(4 / 15)$ sites in 20 years. ${ }^{4}$ To my knowledge, this is the first case report that demonstrates a second attempt at GTR on a previous successfully grafted site which experienced recurrent CAL loss and was thereafter successfully maintained the CAL gain for 5 years. In addition, recommendations pertaining to patient-related and local risk factors for clinicians to consider during maintenance planning of GTR cases are highlighted in this case report. published online September 14, 2021
DOI https://doi.org/

$10.1055 / \mathrm{s}-0041-1731841$ ISSN 1305-7456

\section{(c) 2021. European Journal of Dentistry.}

This is an open access article published by Thieme under the terms of the Creative Commons Attribution-NonDerivative-NonCommercial-License, permitting copying and reproduction so long as the original work is given appropriate credit. Contents may not be used for commercial purposes, or adapted, remixed, transformed or built upon. (https://creativecommons.org/licenses/by-nc-nd/4.0/). Thieme Medical and Scientific Publishers Pvt. Ltd. A-12, 2nd Floor, Sector 2, Noida-201301 UP, India 


\section{Case Presentation}

A healthy, non-smoker 17-year-old Chinese boy presented in 2007 with necrotic pulp and asymptomatic apical periodontitis, perio-endo lesion, and PD of $6 \mathrm{~mm}$ at the mid-palatal region of a fused upper right lateral incisor and upper right canine (\#12-\#13) with two roots sharing a fused crown. Initial periodontal management and root canal treatment were performed on the fused tooth and obturated with Roth's Sealer (Roth International Ltd, Chicago, United States) and Gutta-percha. During an exploration surgery on \#12-\#13 in 2007, a buccal fenestration from the endodontic infection was found between the root of \#12-\#13 with a palatal $10-\mathrm{mm}$ infrabony defect. Hemisection of the root could not be carried out due to the long root trunk. Separation of the crown was not feasible owing to the proximity of both root canals in \#12-\#13 at the cervical region (noticeable in - Fig. 1C). Separating the crown and creating the contour at the cervical region for access to oral hygiene instruction might expose the gutta-percha and potentially causing root resorption in the future. The infrabony defect was grafted with bovine porous bone mineral granules (BioOss, Geistlich) and bioresorbable bovine collagen membrane (BioMend, Geistlich). Composite was applied on the fused crown of \#12-\#13. PD on the mid-palatal region of \#12-\#13 was reduced to $4 \mathrm{~mm}$ and periodontal maintenance was carried out on average every 4.85 months from 2007 to 2009 with a lapse in recall during 2009 to 2012 . Another clinician (author) saw the patient in 2013 with a complaint of a foul smell from the fused tooth. Periodontal examination showed a fused \#12-\#13 (-Fig. 1A) with an increase of PD to $11 \mathrm{~mm}$ noted at the mid-palatal region of \#12-\#13 (-Fig. 1B) with normal mobility and occlusion. The periapical radiograph revealed normal bone level, adequate root-filled, and a slight widening of the periodontal ligament on \#12-\#13 (- Fig. 1C). Nonsurgical periodontal therapy was carried out to debride \#12-\#13 but the deep periodontal PD failed to resolve, leading to exploratory surgery in 2014. During the exploratory surgery, a full mucoperiosteal flap with a simplified papilla preservation technique was raised
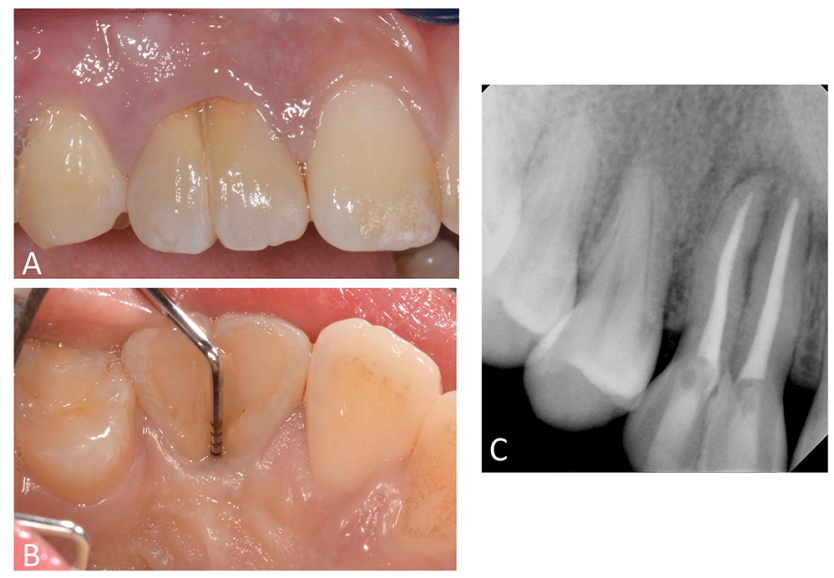

Fig. 1 (A) Preoperative labial view of \#12-\#13. (B) Preoperative palatal view of \#12-\#13 with probing depth $11 \mathrm{~mm}$. (C) Preoperative periapical radiograph on \#12-\#13 from \#11 to \#15. A $V$-shaped, three-walled intrabony defect about $4 \mathrm{~mm}$ in depth was found only on the palatal surface of \#12-\#13 (-Fig. 2A) with intact buccal bone and interdental bone around \#12-\#13. The patient opted to be grafted with the same material because of previous successful surgery; bovine porous bone mineral granules (Bio-Oss, Geistlich) were packed into the defect ( - Fig. 2B). Subsequently, a bioresorbable bovine collagen membrane (BioMend, Geistlich) was trimmed and placed over the bone graft on palatal and extending into the distal part of interdental of \#12-\#13, subsequently stabilized with Vicryl 5/0 suture (Ethicon, Johnson \& Johnson) (-Fig. 2C). The flap closure was completed with the same Vicryl $5 / 0$ suture ( - Fig. 2D). A composite was added to the palatal pit around the region of the fused roots and trimmed following the palatal surface to improve cleansability and reduce plaque retention. The patient was prescribed amoxicillin $500 \mathrm{mg}$ every 8 hours for 5 days, ibuprofen $400 \mathrm{mg}$ every 8 hours for 3 days, and $0.2 \%$ chlorhexidine gluconate mouthwash every 12 hours for 1 week.

The healing of the surgical site was uneventful and the sutures were removed after 1 week. Six months after the second GTR, PD on the mid-palatal region of \#12-\#13 reduced to $4 \mathrm{~mm}$, and no obvious recession was noted ( - Fig. $\mathbf{3 A}$ ). The CAL gain in total was $7 \mathrm{~mm}$. A periapical radiograph that was taken at the 1-year review revealed normal bone level and periapex with no widening of periodontal ligament space ( - Fig. 3B). The patient was seen three monthly for periodontal maintenance and a 4-mm PD has been maintained for the past 5 years ( $\boldsymbol{- \text { Fig. }} \mathbf{4}$ ). In addition, the patient denied any incidence of foul smell from the fused \#12-\#13 since the second GTR was done until the recent 5-year review.

\section{Discussion}

Long-term maintenance regimens for periodontal surgery are not widely discussed and documented. The longest follow-up periods for GTR that have been reported were for over 10 years
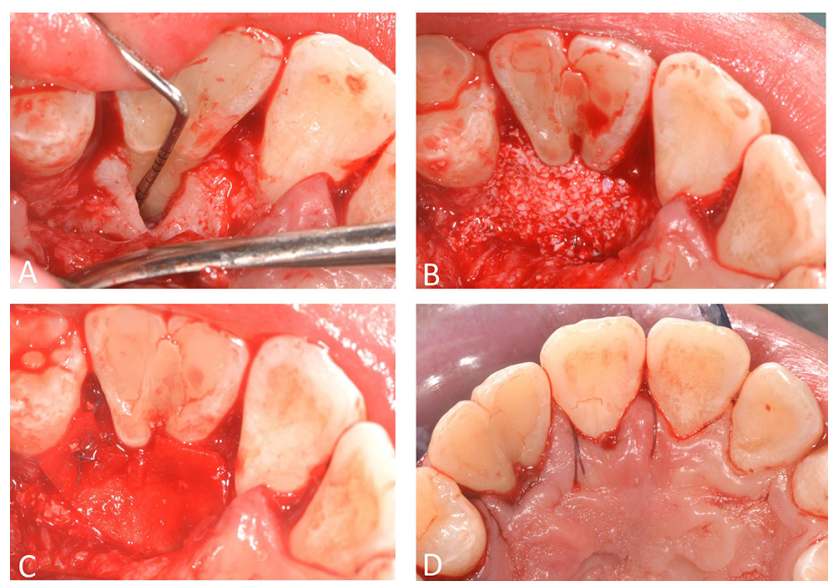

Fig. 2 (A) Intraoperative: Infrabony defect about $4 \mathrm{~mm}$ in depth. (B) Intraoperative: bovine porous bone mineral granules (Bio-Oss, Geistlich) filled the defect. (C) Intraoperative: bioresorbable bovine collagen membrane (BioMend, Geistlich) placed over the bone graft and stabilized with Vicryl 5/0 suture. (D) Postoperative palatal view of flap closure with Vicryl 5/0 suture. 


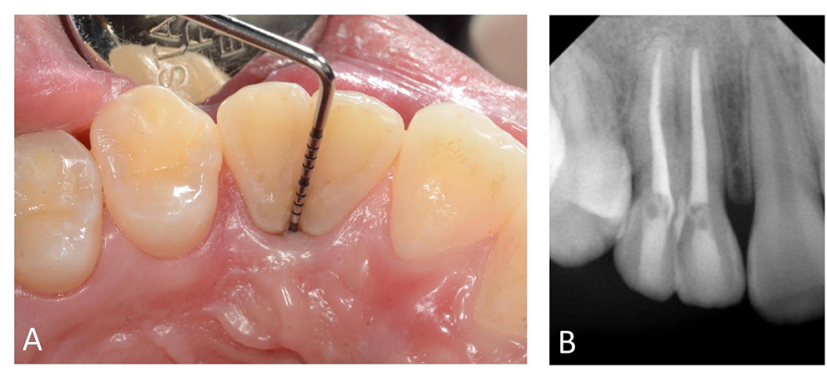

Fig. 3 (A) Probing depth reduced to $4 \mathrm{~mm}$ at 6 months postoperative review. (B) Periapical radiograph at 1-year postoperative review.

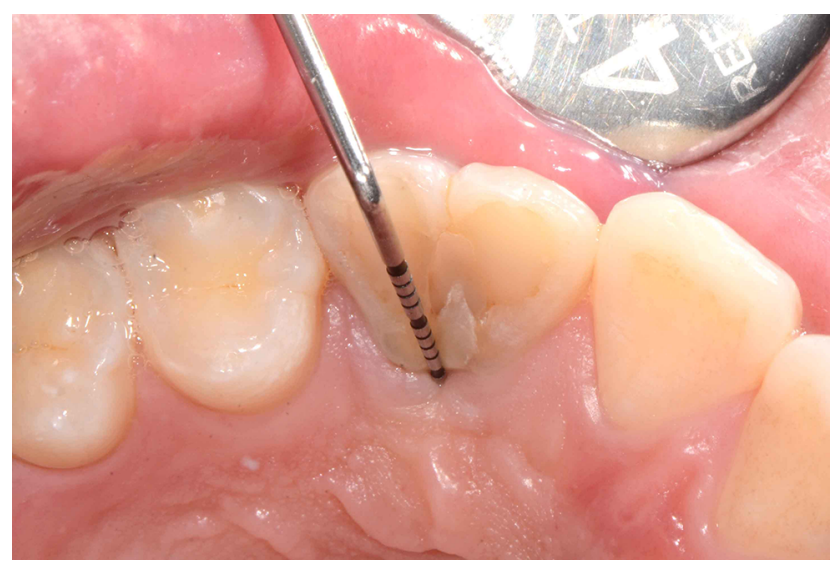

Fig. 4 Probing depth remained at $4 \mathrm{~mm}$ at 5 years postoperative review.

(-Table 1). ${ }^{4-6}$ The maintenance regime that was proposed by the Cortellini et al. and Sculean et al. studies was three monthly. 4.5 This case involved a patient who had 9 months to 1 year maintenance intervals between 2009 and 2012. Besides the local risk factor of the groove between the fused roots of \#12-13 and plaque accumulation around the palatal pit, an irregular maintenance interval and presence of plaque retentive factor could have caused CAL loss after the first GTR. Hence, the second GTR was attempted to eliminate periodontal pocket and achieve attachment gain using bovine bone graft particles and bovine resorbable membrane, which has been shown with new cementum and periodontal ligament with osteogenesis in an 8-months review of histomorphometry analysis. ${ }^{7}$ Plaque retention area on the palatal pit was eliminated by adding composite and the patient was placed on a 3-month periodontal maintenance protocol to prevent periodontal breakdown. This measure has positively led to a good outcome of maintaining a 4-mm PD at the mid-palatal region of \#12-\#13 over the last 5 years. The regenerated attachment has been shown to be no more susceptible to periodontal breakdown compared with normal attachment. ${ }^{8}$ Hence we strongly propose that GTR sites be maintained every 3 months as advocated in long-term $>10$ years GTR studies with good CAL gain ( - Table 1, $2.8 \pm$ $1.2 \mathrm{~mm}$ in Sculean et al, ${ }^{5} 4.9 \pm 2.0 \mathrm{~mm}$ in Cortellini et al, ${ }^{4}$ and $3.8 \pm 2.7 \mathrm{~mm}$ in Petsos et $\mathrm{al}^{6}$ ), especially for patients with a high risk of CAL loss. Additional assessment during periodontal maintenance should include tooth mobility and ascertainment of any plaque retentive areas ( $\mathbf{- T a b l e ~} \mathbf{2}$ ). Jiggling forces around the tooth can disrupt periodontal stability and hasten periodontal breakdown in the presence of plaque and can be controlled via occlusal adjustment ${ }^{9}$ or splinting. ${ }^{10}$

Periodontal breakdown after GTR can be observed over a few years after the procedure. ${ }^{2-4}$ It is prudent for clinicians to formulate good maintenance planning to ensure the prevention of periodontal breakdown or relapse of disease at the previous successfully treated surgical site. Relevant factors for clinicians to consider during maintenance planning can be divided into two main categories: patient risk factors and localized risk factors. Patient risk factors include the patient's health status, plaque control, compliance with a recall program, and smoking habit. Diabetes mellitus, albeit lack in evidence in treated periodontitis patients, can presumably affect the recurrence of the disease. ${ }^{11}$ Periodontitis is known for being the sixth most common complication for patients with diabetes mellitus. ${ }^{12}$ Hyperglycemia can cause immune dysfunction with a reduction in complement and polymorphonuclear cells, as well as reduction in monocytes and T-lymphocytes. The disturbance in innate and cellular immune response inevitably leads to the progression of periodontitis in diabetic patients. Logically, it can be assumed that patients with poor diabetes control require close monitoring of their periodontal condition at shorter maintenance intervals. Patients with positive Interleukin-1 (IL-1) genotype experienced about $50 \%$ loss of first-year CAL gain after 3 years of GTR and about 10 times more likely to experience CAL loss $>2 \mathrm{~mm}$ compared with negative IL-1 genotype patients. ${ }^{18}$ In bacteria-challenging environment, patients with positive IL- 1 genotype can produce over 2-4 times of IL-1 cytokine levels in the gingival crevicular fluid leading to an increase in periodontal inflammation, tooth loss and susceptibility to severe periodontitis. Hence, patients with positive IL-1 genotype will require strict periodontal recall to monitor their periodontal condition. Smoking status is another major consideration in planning good maintenance intervals. Smoking is an important predictor of long-term outcomes of periodontal therapy. ${ }^{13}$ In Cortellini and Tonetti's long-term prospective study on GTR, all six treated teeth which were lost during follow-up were from smokers ( - Table 1).$^{14}$ In addition, smokers tend to be not compliant with scheduled periodontal maintenance visits. ${ }^{15}$ Thus, the maintenance protocol that is planned for smokers should be even more stringent.

Patient compliance with periodontal maintenance is an important factor in maintaining the grafted site. Regular periodontal maintenance is crucial in preventing disease progression and leads to better prognosis. ${ }^{16,17}$ Five out of the six teeth that were lost in the long-term follow-up after GTR were from subjects who failed to attend regular periodontal maintenance. ${ }^{14}$ Further, noncompliant dental attenders for periodontal maintenance demonstrated an increase in attachment loss. ${ }^{16,17}$ On the other hand, participation in a periodontal recall program decreased failure of GTR $^{13,14}$ and should thus be advocated for all GTR patients. Since microbe load in the patient's mouth is related to disease progression, the disruption of the biofilm during mechanical debridement in a periodontal maintenance visit can halt the ongoing destructive process in the periodontium ( - Table 2 ). Therefore, clinicians need to educate patients about the importance of maintenance and compliance with the recall 
Table 1 Summary of literature review on periodontal maintenance after Guided Tissue Regeneration (GTR)

\begin{tabular}{|c|c|c|c|c|c|c|}
\hline No. & Study & $\begin{array}{l}\text { Number of } \\
\text { subjects/sites }\end{array}$ & GTR method & Average SPT & $\begin{array}{l}\text { Follow-up } \\
\text { period } \\
\text { (mean) }\end{array}$ & Outcomes \\
\hline 1 & $\begin{array}{l}\text { Gottlow et al } 1992^{19} \\
\text { (non-randomized } \\
\text { clinical trial). }\end{array}$ & $\begin{array}{l}39 \text { subjects, } 88 \\
\text { sites }\end{array}$ & PTFE membrane & Not reported & $5 y$ & $\begin{array}{l}90.9 \%(80 / 88) \text { of sites CAL gain }>2 \\
\text { mm, and the } 80 \text { sites were included } \\
\text { for follow-up. } 75 \%(60 / 80) \text { of sites } \\
\text { CAL gain } \geq 3 \mathrm{~mm}, 15 \%(12 / 80) \text { of } \\
\text { sites CAL loss } \geq 2 \mathrm{~mm} \text { in } 3 \mathrm{y} \text {. } \\
\text { No CAL loss of }>2 \mathrm{~mm} \text { at } 4 \text { and } 5 \mathrm{y} \text {. }\end{array}$ \\
\hline 2 & $\begin{array}{l}\text { Cortellini et al } \\
1996^{17} \\
\text { (non-randomized } \\
\text { clinical trial). }\end{array}$ & $\begin{array}{l}44 \text { subjects, } \\
175 / 175 \text { sites }\end{array}$ & $\begin{array}{l}\text { Teflon mem- } \\
\text { brane (Gore-tex } \\
\text { periodontal } \\
\text { membrane). }\end{array}$ & $\begin{array}{l}\text { - First year: } \\
\text { monthly. } \\
\text { - Thereafter SPT: } \\
\text { every } 3 \text { mo. }\end{array}$ & $5 y$ & $\begin{array}{l}\text { CAL gain was } 4.0 \pm 2.1 \mathrm{~mm} \text { at } 1 \mathrm{y} \\
\text { CAL loss was } 1.2 \pm 1.4 \mathrm{~mm} \text { at } 5 \mathrm{y} \text {. }\end{array}$ \\
\hline 3 & $\begin{array}{l}\text { Cortellini and } \\
\text { Tonetti } 2004^{14} \\
\text { (non-randomized } \\
\text { clinical trial). }\end{array}$ & $\begin{array}{l}175 \text { subjects, } \\
175 \text { sites }\end{array}$ & $\begin{array}{l}\text { Nonabsorbable } \\
\text { membrane } \\
\text { (ePTFE), absorb- } \\
\text { able membrane } \\
\text { (PLA), with or } \\
\text { without alloplastic } \\
\text { materials. }\end{array}$ & $\begin{array}{l}\text { - First year: } \\
\text { monthly } \\
\text { prophylaxis. } \\
\text { - Thereafter } \\
\text { SPT: every } 3 \\
\text { mo }(117 / 175 \\
\text { subjects } \\
\text { assessed }) \text {. }\end{array}$ & $\begin{array}{l}\text { Longest } 16 \\
\text { y, average } \\
8 \pm 3.4 \mathrm{y}\end{array}$ & $\begin{array}{l}\text { Six teeth lost (all smokers, } 5 \text { without } \\
\text { SPT). } \\
\text { Mean CAL gain } 4.6 \pm 2.0 \mathrm{~mm} \text { at } 1 \mathrm{y} \text {, } \\
66.2 \% \text { with no CAL loss of } \geq 2 \mathrm{~mm} \\
\text { over } 16 \mathrm{y} \text {. }\end{array}$ \\
\hline 4 & $\begin{array}{l}\text { Sculean et al } 2008^{5} \\
\text { (randomized con- } \\
\text { trolled clinical trial). }\end{array}$ & $\begin{array}{l}19 \text { subjects } \\
\text { GTR: } 10 \text { sites, } \\
\text { EMD+GTR: } 9 \\
\text { sites. }\end{array}$ & $\begin{array}{l}\text { GTR with or } \\
\text { without EMD } \\
\text { Emdogain, } \\
\text { GTR using } \\
\text { Resolut, Gore-Tex } \\
\text { membrane. }\end{array}$ & $\begin{array}{l}\text { - } 6 \text { wk of } \\
\text { chlorhexidine } \\
\text { mouth rinse. } \\
\text { - Fortnightly } \\
\text { visit for the } \\
\text { first } 2 \text { mo, } \\
\text { monthly visit } \\
\text { for the first } \\
\text { year. } \\
\text { - Subsequently, } \\
\text { four visits per } \\
\text { year (every } 3 \\
\text { mo). }\end{array}$ & $10 y$ & $\begin{array}{l}\text { GTR group: CAL gain of } 3.2 \pm 1.4 \\
\mathrm{~mm} \text { at } 1 \mathrm{y} \text { and } 2.8 \pm 1.2 \mathrm{~mm} \text { at } 10 \mathrm{y} \text {. } \\
\text { CAL loss of } 0.4 \pm 1.2 \mathrm{~mm} \text { at } 10 \mathrm{y} . \\
\text { EMD+GTR group: CAL gain of } 3.3 \\
\pm 1.1 \mathrm{~mm} \text { at } 1 \mathrm{y} \text { and } 2.9 \pm 1.2 \mathrm{~mm} \\
\text { at } 10 \mathrm{y} . \text { CAL loss of } 0.4 \pm 1.2 \mathrm{~mm} \\
\text { at } 10 \mathrm{y} \text {. } \\
\text { Note: } 5 \text {-y follow-up was reported by } \\
\text { Sculean et al } 2004 .^{20}\end{array}$ \\
\hline 5 & $\begin{array}{l}\text { Stavropoulus and } \\
\text { Karring } 2005^{3} \\
\text { (case series). }\end{array}$ & $\begin{array}{l}11 \text { subjects; } 11 \\
\text { sites }\end{array}$ & $\begin{array}{l}\text { Deproteinized } \\
\text { bovine protein } \\
\text { impregnated } \\
\text { with } 2 \mathrm{mg} / \\
\mathrm{mL} \text { gentamicin } \\
\text { sulfate and PLA/ } \\
\text { PGA Resolut } \\
\text { membrane. }\end{array}$ & $\begin{array}{l}\text { - Prophylaxis } \\
\text { weekly for first } \\
6 \text { wk. } \\
\text { - Monthly } \\
\text { prophylaxis till } \\
5 \text { mo. } \\
\text { - No further } \\
\text { information } \\
\text { on subsequent } \\
\text { recalls. }\end{array}$ & $5 y$ & $\begin{array}{l}\text { Two teeth lost. } \\
\text { CAL gain of } 3.8 \pm 1.9 \mathrm{~mm} \text { at } 1 \mathrm{y} \text { and } \\
4.1 \pm 1.6 \mathrm{~mm} \text { at } 5 \mathrm{yr} \text {. } \\
36.4 \%(4 / 11) \text { sites with CAL loss. }\end{array}$ \\
\hline 6 & $\begin{array}{l}\text { Slotte et al } 2007^{2} \\
\text { (case series). }\end{array}$ & $\begin{array}{l}24 \text { subjects; } 24 \\
\text { sites }\end{array}$ & $\begin{array}{l}\text { Deproteinized } \\
\text { bovine protein } \\
\text { (BioOss) } \\
\text { bioresorbable } \\
\text { membrane } \\
\text { (Guidor/BioGide). }\end{array}$ & $\begin{array}{l}\text { - Fortnightly } \\
\text { visit for the } \\
\text { first } 3 \text { mo. } \\
\text { - Once a month } \\
\text { for the next } 3 \\
\text { mo. } \\
\text { - No details on } \\
\text { subsequent } \\
\text { recalls. }\end{array}$ & $5 y$ & $\begin{array}{l}\text { Mean gain in CAL was } 4.2 \pm 2.1 \mathrm{~mm} \\
\text { at } 1 \mathrm{y}, 4.1 \pm 1.8 \mathrm{~mm} \text { at } 3 \mathrm{y} \text {, and } 4.3 \pm \\
2.0 \mathrm{~mm} \text { at } 5 \text { y examinations. } \\
20.8 \% \text { (5/24) of sites with CAL loss, } \\
\text { two sites were from a smoker. }\end{array}$ \\
\hline 7 & $\begin{array}{l}\text { Cortellini et al } 2017^{4} \\
\text { (randomized con- } \\
\text { trolled clinical trial). }\end{array}$ & $\begin{array}{l}30 \text { subjects; } 30 \\
\text { sites }\end{array}$ & $\begin{array}{l}\text { Titanium PTFE } \\
(n=15), \text { PTFE } \\
\text { membrane }(n \\
=15), \text { with or } \\
\text { without alloplastic } \\
\text { materials. }\end{array}$ & $\begin{array}{l}\text { - First year: } \\
\text { monthly. } \\
\text { - Thereafter: } \\
\text { every } 3 \text { mo. }\end{array}$ & $20 y$ & $\begin{array}{l}\text { No tooth lost. } \\
\text { Mean CAL gain of } 4.9 \pm 2.0 \mathrm{~mm} \text { at } \\
20 \mathrm{y} \text { for Titanium PTFE and } 6.7 \pm \\
2.0 \mathrm{~mm} \text { for PTFE membrane. Mean } \\
\text { CAL loss of } 0.1 \pm 0.3 \mathrm{~mm} \text { at } 20 \mathrm{y} \text { for } \\
\text { Titanium PTFE and } 0.5 \pm 0.1 \mathrm{~mm} \\
\text { at } 20 \text { y for PTFE membrane. } 26.7 \% \\
(4 / 15) \text { of sites with CAL loss. }\end{array}$ \\
\hline
\end{tabular}

(Continued) 
Table 1 (Continued)

\begin{tabular}{|c|c|c|c|c|c|c|}
\hline No. & Study & $\begin{array}{l}\text { Number of } \\
\text { subjects/sites }\end{array}$ & GTR method & Average SPT & $\begin{array}{l}\text { Follow-up } \\
\text { period } \\
\text { (mean) }\end{array}$ & Outcomes \\
\hline 8 & $\begin{array}{l}\text { Petsos et al } 2019^{6} \\
\text { (randomized con- } \\
\text { trolled clinical trial). }\end{array}$ & $\begin{array}{l}12 \text { subjects; } \\
25 \text { sites }\end{array}$ & $\begin{array}{l}\text { PLA membrane } \\
\text { (Guidor). Split } \\
\text { mouth }(n=10), \\
\text { Parallel } \\
(n=15)\end{array}$ & $\begin{array}{l}\text { - Recall at } 3,6, \\
12 \text { mo. } \\
\text { - Subsequently, } \\
\text { patients who } \\
\text { came back } \\
\text { at least once } \\
\text { per year were } \\
\text { considered } \\
\text { compliant. } \\
\text { Subseque nt } \\
\text { recalls not well } \\
\text { described. }\end{array}$ & $20 y$ & $\begin{array}{l}4 \text { GTR-treated teeth extracted due } \\
\text { to prosthodontic reasons. } \\
\text { CAL gain was } 3.90 \pm 2.76 \mathrm{~mm} \text { at } 10 \\
\text { y and } 3.80 \pm 2.69 \mathrm{~mm} \text { at } 20 \mathrm{y} \text {. CAL } \\
\text { change was } 0.78 \pm 1.93 \mathrm{~mm} \text { at } 10 \mathrm{y} \text {, } \\
\text { and } 0.30 \pm 0.21 \mathrm{~mm} \text { (split mouth) } \\
\text { and } 0.93 \pm 0.66 \mathrm{~mm} \text { (parallel) at } 20 \\
\text { y. } 1 \mathrm{GTR} \text {-treated tooth with CAL loss } \\
>2 \mathrm{~mm} \text { at } 10 \mathrm{yr}, 2 \text { GTR-treated teeth } \\
\text { with CAL loss }>2 \mathrm{~mm} \text { at } 20 \mathrm{yr} \text {. } \\
\text { Note: } 10 \text {-y follow-up was reported } \\
\text { by Nickles et al } 2009 .^{21}\end{array}$ \\
\hline
\end{tabular}

Abbreviations: CAL, clinical attachment level; EMD, enamel matrix derivatives; ePTFE, expanded polytetrafluoroethylene; GTR, guided tissue regeneration; PGA, polyglycolic acid; PLA, polylactic acid; PTFE, polytetrafluoroethylene; SPT, supportive periodontal therapy.

anly subjects who were treatment compliant were analyzed

Table 2 Considerations for planning periodontal maintenance after guided tissue regeneration (GTR)

\begin{tabular}{|c|c|c|}
\hline \multicolumn{2}{|c|}{ Assessment in periodontal maintenance } & Rationale and management \\
\hline \multicolumn{2}{|c|}{ Plaque retentive factor } & Promotes plaque accumulation, needs to be eliminated. ${ }^{22}$ \\
\hline \multicolumn{2}{|l|}{ Tooth mobility } & $\begin{array}{l}\text { Jiggling force disturbs periodontal stability, requires occlusal adjustment }{ }^{9} \text { or } \\
\text { splinting. } .^{10}\end{array}$ \\
\hline \multicolumn{2}{|c|}{ Periodontal maintenance planning factors } & Rationale (Proposal for three monthly maintenance) \\
\hline \multirow[t]{3}{*}{ Patient related } & Systemic condition & Diabetes ${ }^{11}$ and IL-1 polymorphism positive ${ }^{18}$ patients are associated with CAL loss. \\
\hline & Smoking & $\begin{array}{l}\text { Smoking affects GTR outcome } \mathrm{e}^{23,24} \text { and disease progression. }{ }^{25} \\
\text { Hazard ratio of } 7.2 \text { for regenerated CAL loss } \geq 2 \mathrm{~mm} .{ }^{14}\end{array}$ \\
\hline & $\begin{array}{l}\text { Compliance to periodontal } \\
\text { maintenance }\end{array}$ & $\begin{array}{l}\text { Mechanical disruption of biofilm during maintenance is important to halt disease } \\
\text { progression. } .^{11,16} \\
\text { Increase in CAL loss in noncompliant attenders. }{ }^{16,17}\end{array}$ \\
\hline \multirow[t]{2}{*}{ Local } & Plaque control & Full mouth plaque score more than $10 \%{ }^{14}$ \\
\hline & Residual pockets & $\begin{array}{l}\text { Residual pockets are a reservoir for periodontal pathogens. High-risk disease } \\
\text { progression } \geq 8 \text { residual pockets, low risk } \leq 4 \text { residual pockets. }{ }^{11}\end{array}$ \\
\hline
\end{tabular}

Abbreviations: CAL, clinical attachment level; GTR, guided tissue regeneration.

system at the beginning of the treatment. Finally, local factors such as plaque control and residual pockets can affect the stability of attachment after regeneration. Patients with a plaque score $>10 \%{ }^{14}$ and $\geq 8$ residual pockets are at risk of loss of attachment at the regenerated site and should have a short periodontal recall interval. ${ }^{11}$

The limitation of this report is no clinical photo documentation from the previous operator during the first GTR attempt in 2007, hence we could not observe the bony defect at the first grafting procedure. The potential research focus for GTR in the future can include the investigation of the effect of different periodontal maintenance intervals after GTR; the prevalence and factors associated with periodontal breakdown after GTR; the success rate and changes in CAL after second GTR, and the resistance of regenerated attachment against periodontitis after second GTR.

\section{Conclusion}

This case report showed that GTR can be performed on a previous successfully grafted site where there is a recurrence of periodontal breakdown to achieve PD reduction and CAL gain. Good maintenance planning taking into consideration patient-related and local risk factors is crucial to prevent periodontal breakdown at the GTR site.

\section{Funding}

None.

\section{Conflict of Interest}

None declared.

\section{Acknowledgments}

The author would like to thank Dr. Marianne Ong for critically reviewing this manuscript and Ms. Safiyya Mohamed Ali for providing editorial support.

\section{References}

1 Cortellini P, Tonetti MS. Focus on intrabony defects: guided tissue regeneration. Periodontol 2000;22:104-132

2 Slotte C, Asklöw B, Lundgren D. Surgical guided tissue regeneration treatment of advanced periodontal defects: a 5-year follow-up study. J Clin Periodontol 2007;34(11):977-984 
3 Stavropoulos A, Karring T. Five-year results of guided tissue regeneration in combination with deproteinized bovine bone (Bio-Oss) in the treatment of intrabony periodontal defects: a case series report. Clin Oral Investig 2005;9(4):271-277

4 Cortellini P, Buti J, Pini Prato G, Tonetti MS. Periodontal regeneration compared with access flap surgery in human intra-bony defects 20-year follow-up of a randomized clinical trial: tooth retention, periodontitis recurrence and costs. J Clin Periodontol 2017;44(1):58-66

5 Sculean A, Kiss A, Miliauskaite A, Schwarz F, Arweiler NB, Hannig M. Ten-year results following treatment of intra-bony defects with enamel matrix proteins and guided tissue regeneration. J Clin Periodontol 2008;35(9):817-824

6 Petsos H, Ratka-Krüger P, Neukranz E. Raetzke P, Eickholz P, Nickles K. Infrabony defects 20 years after open flap debridement and guided tissue regeneration. J Clin Periodontol 2019;46(5):552-563

7 Sculean A, Stavropoulos A, Windisch P, Keglevich T, Karring T, Gera I. Healing of human intrabony defects following regenerative periodontal therapy with a bovine-derived xenograft and guided tissue regeneration. Clin Oral Investig 2004;8(2):70-74

8 Ling LJ, Lai $\mathrm{YH}$, Hwang $\mathrm{H}$, Chen $\mathrm{H}$. Response of regenerative tissues to plaque: a histological study in monkeys. J Periodontol 1994;65(8):781-787

9 Vollmer WH, Rateitschak KH. Influence of occlusal adjustment by grinding on gingivitis and mobility of traumatized teeth. J Clin Periodontol 1975;2(3):113-125

10 Schulz A, Hilgers RD, Niedermeier W. The effect of splinting of teeth in combination with reconstructive periodontal surgery in humans. Clin Oral Investig 2000;4(2):98-105

11 Lang NP, Tonetti MS. Periodontal risk assessment (PRA) for patients in supportive periodontal therapy (SPT) Oral Health Prev Dent 2003;1(1):7-16

12 Löe H. Periodontal disease. The sixth complication of diabetes mellitus. Diabetes Care 1993;16(1):329-334

13 McGuire MK, Nunn ME. Prognosis versus actual outcome. III. The effectiveness of clinical parameters in accurately predicting tooth survival. J Periodontol 1996;67(7):666-674

14 Cortellini P, Tonetti MS. Long-term tooth survival following regenerative treatment of intrabony defects. J Periodontol 2004;75(5):672-678
15 Ramseier CA, Kobrehel S, Staub P, Sculean A, Lang NP, Salvi GE. Compliance of cigarette smokers with scheduled visits for supportive periodontal therapy. J Clin Periodontol 2014;41(5):473-480

16 Axelsson P, Nyström B, Lindhe J. The long-term effect of a plaque control program on tooth mortality, caries and periodontal disease in adults. Results after 30 years of maintenance. J Clin Periodontol 2004;31(9):749-757

17 Cortellini P, Paolo G, Prato P, Tonetti MS. Long-term stability of clinical attachment following guided tissue regeneration and conventional therapy. J Clin Periodontol 1996;23(2):106-111

18 De Sanctis M, Zucchelli G, Interleukin-1 gene polymorphisms and long-term stability following guided tissue regeneration therapy. J Periodontol 2000;71(4):606-613

19 Gottlow J, Nyman S, Karring T. Maintenance of new attachment gained through guided tissue regeneration. J Clin Periodontol 1992;19(5):315-317

20 Sculean A, Donos N, Schwarz F, Becker J, Brecx M, Arweiler NB. Five-year results following treatment of intrabony defects with enamel matrix proteins and guided tissue regeneration. J Clin Periodontol 2004;31(7):545-549

21 Nickles K, Ratka-Krüger P, Neukranz E. Raetzke P, Eickholz P. Open flap debridement and guided tissue regeneration after 10 years in infrabony defects. J Clin Periodontol 2009;36(11):976-983

22 Lindhe J, Nyman S. The effect of plaque control and surgical pocket elimination on the establishment and maintenance of periodontal health. A longitudinal study of periodontal therapy in cases of advanced disease. J Clin Periodontol 1975;2(2):67-79

23 Grossi SG, Skrepcinski FB, DeCaro T, Zambon JJ, Cummins D, Genco RJ. Response to periodontal therapy in diabetics and smokers. J Periodontol 1996;67:1094-1102

24 Kaldahl WB, Kalkwarf KL, Patil KD, Molvar MP, Dyer JK. Long-term evaluation of periodontal therapy: II. Incidence of sites breaking down. J Periodontol 1996;67(2):103-108

25 Tonetti MS. Cigarette smoking and periodontal diseases: etiology and management of disease. Ann Periodontol 1998;3(1):88-101 